\title{
SIKLON TROPIS, KARASTERISTIK DAN PENGARUHNYA DI WILAYAH INDONESIA PADA TAHUN 2012
}

\author{
M. Djazim Syaifullah ${ }^{1)}$ \\ ${ }^{1}$ UPT Hujan Buatan - BPPT, Jalan MH Thamrin no 8, Jakarta Pusat
}

\begin{abstract}
Intisari
Tulisan ini adalah sebuah dan analisis karasteristik dari siklon tropis termasuk proses siklus hidupnya, struktur, skala kekuatan dan bagaimana pengaruhnya di daerah Indonesia. Analisis siklon tropis dikhususkan untuk kejadian-kejadian di daerah Pasifik Barat dan Laut Cina Selatan. Salah satu pengaruh siklon tropis adalah munculnya hotspot di Sumatera dan Kalimantan. Siklon tropis adalah sebuah yang fenomena meteorologi yang dengan potensi besar dampak di area kerusakan yang dilaluinya. Siklon tropis mempunyai kekuatan yang sangat besar dan tidak ada usaha manusia yang dapat mencegah atau menghilangkan siklon tropis. Siklon Tropis mempunyai siklus mulai sejak saat pembentukannya sampai kepunahannya. Ada tiga tahap : tahap pembentukan, tahap matang dan tahap pelemahan. Indonesia secara umum mendapatkan pengaruh secara tidak langsung dari keberadaan siklon tropis ini, dimana pada musim kering ini akan memperparah bencana kekeringan di beberapa daerah di Indonesia khususnya di wilayah Kalimantan dan Sumatera.
\end{abstract}

Kata Kunci: siklon tropis, kebakaran hutan, hotspot

\begin{abstract}
This paper is an overview and analisys of tropical cyclone charasteristics consit of their life cycle processes, structures, scale of strength and how its influence in Indonesian region. Tropical cyclone analysis is devoted to the events in the Western Pacific region and the South China Sea. Observed influence of tropical cyclones is the emergence of hot spots in Sumatera and Kalimantan as well as it happened rains in some areas. The tropical cyclone is a meteorological phenomenon with huge potential impact on the area of damage in its path. Tropical cyclone strength was so big and there was no human effort that can prevent or eliminate a tropical cyclone. Tropical cyclones have a life cycle starting from the moment of its formation until its extinction. There are three stages : formation stage, mature stage and attenuation stage. Indonesia generally received indirect impact on changing weather conditions. In the dry season will increase the incidence of tropical cyclone severe drought level in the region of Indonesia, particularly Sumatera and Kalimantan and result in the emergence of the number of fires (hot spot) which is quite a lot. In the wet season tropical cyclone events can cause increased rainfall causes floods, especially in areas close to the location of the cyclone, for example in the area of the northern part of Kalimantan and Sulawesi.
\end{abstract}

Keywords : tropical cyclone, forest fire, hotspot

\section{PENDAHULUAN}

Bencana alam adalah bencana yang diakibatkan oleh peristiwa atau serangkaian peristiwa yang disebabkan oleh alam antara lain berupa gempa bumi, tsunami, gunung meletus, banjir, kekeringan, angin topan, dan tanah longsor. Jika bencana tersebut sudah berskala luas dan berskala nasional maka sudah menjadi bencana nasional. Bencana-bencana hidrometeorologi seperti banjir, longsor, kekeringan, kebakaran lahan dan hutan diyakini berpotensi melanda Indonesia hampir setiap tahun.

Indonesia merupakan penghasil emisi gas rumah kaca terbesar ketiga di dunia setelah Cina dan Amerika Serikat, hal ini sebagian besar disebabkan oleh deforestasi, konversi lahan dan kebakaran hutan dan lahan. Dampak yang ditimbulkan kebakaran hutan ternyata sangat kompleks, selain berdampak terhadap ekologi dan mengakibatkan kerusakan lingkungan saja tetapi juga terhadap kehidupan sosial, budaya, dan ekonomi, dampak terhadap ekologis dan kerusakan lingkungan, dampak terhadap hubungan antar negara, serta dampak terhadap perhubungan dan pariwisata. Dampak terhadap sosial, budaya dan ekonomi misalnya : terganggunya aktivitas sehari-hari, menurunnya produktivitas serta hilangnya sejumlah mata pencaharian masyarakat di dan sekitar hutan. Asap hasil kebakaran hutan menjadi masalah 
serius bukan hanya di daerah sekitar hutan saja. Asap terbawa angin hingga ke daerah lain bahkan mencapai berbagai negara tetangga seperti Singapura, Malaysia, dan Brunei Darussalam akan mempengaruhi hubungan baik antar kedua negara.

Kebakaran hutan terjadi karena kondisi lahan yang sangat kering akibat musim kering yang mencekam, ditambah juga karena faktor manusia dalam melakukan pengelolaan sumber daya hutan yang tidak tepat. Kondisi yang kering pada musim kering diperparah dengan adanya siklon tropis yang mempengaruhi sebagian wilayah Indonesia. Oleh karena itu perlu dipahami pengaruh siklon tropis di beberapa wilayah di Indonesia terutama pada musim kering.

Tulisan ini merupakan overview tentang siklon tropis baik dari proses hidup, siklus, struktur, skala kekuatannya dan bagaimana pengaruhnya di wilayah Indonesia baik secara langsung maupun tidak langsung, sehingga dengan diketahui karasteristik bencana ini dapat dilakukan adaptasi maupun mitigasi terhadap jenis bencana ini. Analisis siklon tropis ini dikhususkan untuk wilayah kejadian di Pasifik Barat dan Laut China Selatan. Pengaruh yang diamati terhadap kejadian siklon tropis adalah kemunculan titik panas (hotspot) di Sumatera dan Kalimantan serta kejadia hujan di beberapa wilayah.

\section{SIKLON TROPIS}

Siklon tropis didefinisikan sebagai sistem tekanan rendah non-frontal yang berskala sinoptik yang tumbuh di atas perairan hangat dengan wilayah perawanan konvektif dan kecepatan angin maksimum sedikitnya 34 knot pada lebih dari setengah wilayah yang melingkari pusatnya, serta bertahan setidaknya enam jam. Siklon tropis merupakan badai dengan kekuatan yang besar. Radius rata-rata siklon tropis mencapai 150 hingga $200 \mathrm{~km}$. Siklon tropis terbentuk di atas lautan luas yang umumnya mempunyai suhu permukaan air laut hangat, lebih dari $26.5^{\circ} \mathrm{C}$. Kadangkala di pusat siklon tropis terbentuk suatu wilayah dengan kecepatan angin relatif rendah dan tanpa awan yang disebut dengan mata siklon. Diameter mata siklon bervariasi mulai dari 10 hingga $100 \mathrm{~km}$. Mata siklon ini dikelilingi dengan dinding mata, yaitu wilayah berbentuk cincin yang dapat mencapai ketebalan $16 \mathrm{~km}$, yang merupakan wilayah dimana terdapat kecepatan angin tertinggi dan curah hujan terbesar.

Masa hidup suatu siklon tropis rata-rata berkisar antara 3 hingga 18 hari. Karena energi siklon tropis didapat dari lautan hangat, maka siklon tropis akan melemah atau punah ketika bergerak dan memasuki wilayah perairan yang dingin atau memasuki daratan. Siklon tropis dikenal dengan berbagai istilah : jika terbentuk di Samudra Pasifik Barat maka disebut "badai tropis" atau "typhoon" atau "topan", jika terbentuk di sekitar India atau Australia disebut "siklon" atau "cyclone", dan jika terbentuk di Samudra Atlantik Utara, Samudera Pasifik Timur disebut "hurricane". Angin dengan kecepatan tertinggi ini biasanya terdapat di wilayah cincin di dekat pusat siklon, atau jika siklon ini memiliki mata, berada di dinding mata. Ukuran siklon tropis bervariasi. mulai dari $50 \mathrm{~km}$ (Cyclone Tracy, 1977) - 1100 km (Typhoon Tip, 1979).

Daerah pertumbuhan siklon tropis mencakup Atlantik Barat, Pasifik Timur, Pasifik Utara bagian barat, Samudera Hindia bagian utara dan selatan, Australia dan Pasifik Selatan. Sekitar 2/3 kejadian siklon tropis terjadi di belahan bumi bagian utara. Sekitar $65 \%$ siklon tropis terbentuk di daerah antara $10^{\circ}-20^{\circ}$ dari ekuator, hanya sekitar $13 \%$ siklon tropis yang tumbuh diatas daerah lintang di atas $20^{\circ}$, sedangkan di daerah lintang rendah $\left(0^{\circ}\right.$. $\left.10^{\circ} \mathrm{LS} / \mathrm{LU}\right)$ siklon tropis jarang terbentuk.

\subsection{Proses Terbentuknya Siklon Tropis}

Seperti namanya, siklon tropis tumbuh diperairan disekitar daerah tropis, terutama yang memiliki suhu muka laut yang hangat. Jumlah siklon tropis yang tumbuh dibelahan bumi utara rata-rata 57.3 kejadian dalam satu tahun dan dibelahan bumi selatan rata-rata 26.3 siklon tropis dalam setahun (berdasarkan data tahun 1968 - 1989). Siklon tropis dapat terbentuk dengan persyaratan berikut ini (BMKG, 2011):

- Suhu permukaan laut sekurang-kurangnya $26.5^{\circ} \mathrm{C}$ hingga ke kedalaman 60 meter.

- Kondisi atmosfer tidak stabil, memungkinkan terbentuknya awan Cumulonimbus. Tipe awan ini, yang merupakan awan-awan guntur, merupakan indikator konvektif kuat.

- Atmosfer yang relatif lembab di ketinggian sekitar 5 km ( $\approx 15$ ribu kaki). Ketinggian ini merupakan atmosfer paras menengah, yang apabila dalam keadaan kering tidak dapat mendukung bagi perkembangan aktivitas badai guntur di dalam siklon.

- Gangguan atmosfer di dekat permukaan bumi berupa angin yang berpusar yang disertai dengan pumpunan angina (konvergensi).

- Perubahan kondisi angin terhadap ketinggian tidak terlalu besar. Perubahan kondisi angin yang besar akan mengacaukan proses perkembangan badai guntur.

\subsection{Siklus Hidup Siklon Tropis}

Seperti halnya fenomena cuaca lainnya, siklon tropis juga mempunyai siklus hidup mulai dari proses pembentukannya hingga saat 
kepunahannya. Siklus hidup siklon tropis dapat dibagi menjadi empat tahapan, yaitu :

Tahap Pembentukan : Ditandai dengan adanya gangguan atmoster. Jika dilihat dari citra satelit cuaca, gangguan ini ditandai dengan wilayah konvektif dengan awan-awan cumulonimbus. Pusat sirkulasi seringkali belum terbentuk, namun kadangkala sudah nampak pada ujung sabuk perawanan yang membentuk spiral.

Tahap Belum Matang : Pada tahap ini wilayah konvektif kuat terbentuk lebih teratur membentuk sabuk perawanan melingkar (berbentuk spiral) atau membentuk wilayah yang bentuknya relatif bulat. Intensitasnya meningkat secara simultan ditandai dengan tekanan udara permukaan yang turun mencapai kurang $<1000$ mb serta kecepatan angin maksimum yang meningkat hingga mencapai gale force wind (kecepatan angin $\geq 34 \mathrm{knot}$ atau $63 \mathrm{~km} / \mathrm{jam}$ ). Angin dengan kecepatan maksimum terkonsentrasi pada cincin yang mengelilingi pusat sirkulasi. Pusat sirkulasi terpantau jelas dan mulai tampak terbentuknya mata siklon.

Tahap Matang : Pada tahap matang, bentuk siklon tropis cenderung stabil. Sirkulasi siklonik dan wilayah dengan gale force wind meluas, citra satelit cuaca menunjukkan kondisi perawanan teratur dan lebih simetris. Pada siklon tropis yang lebih kuat dapat jelas terlihat adanya mata siklon. Fenomena ini ditandai dengan wilayah bersuhu paling hangat di tengah-tengah sistem perawanan dengan angin permukaan yang tenang dan dikelilingi oleh dinding perawanan konvektif tebal di sekelilingnya (dinding mata). Kecuali jika siklon tropis berada di wilayah yang sangat mendukung perkembangannya, tahap matang biasanya hanya bertahan selama kurang lebih 24 jam sebelum intensitasnya mulai melemah.

Tahap Pelemahan : Pada tahap punah, pusat siklon yang hangat mulai menghilang, tekanan udara meningkat dan wilayah dengan kecepatan angin maksimum meluas dan melebar menjauh dari pusat siklon. Tahap ini dapat terjadi dengan cepat jika siklon tropis melintas di wilayah yang tidak mendukung bagi pertumbuhannya, seperti misalnya memasuki wilayah perairan lintang tinggi dengan suhu muka laut yang dingin atau masuk ke daratan. Dari citra satelit dapat terlihat jelas bahwa wilayah konvektif siklon tropis tersebut berkurang, dan sabuk perawanan perlahan menghilang. Waktu rata-rata yang dibutuhkan sebuah siklon tropis dari mulai tumbuh hingga punah adalah sekitar 7 (tujuh) hari, namun variasinya bisa mencapai 1 hingga 30 hari.

\subsection{Struktur Siklon Tropis}

Sebuah siklon tropis dengan intensitas kuat umumnya mempunyai struktur dan digambarkan seperti pada Gambar 1. sebagai berikut (Pustekkom, 2005) :

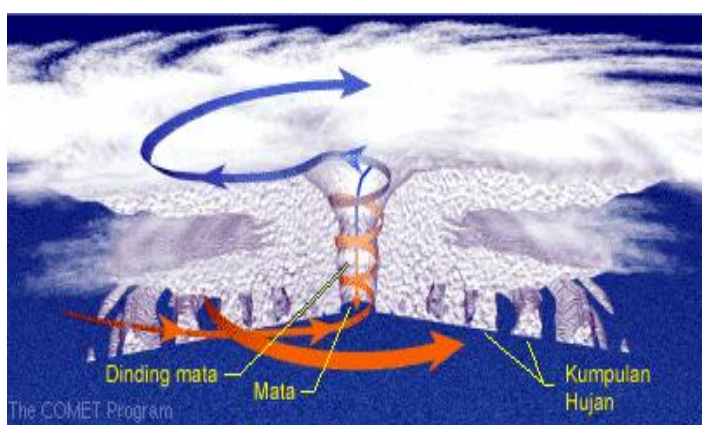

Gambar 1. Struktur siklon tropis

- Low Pressure (Tekanan Permukaan Rendah); Siklon tropis berputar di sekitar daerah bertekanan udara permukaan rendah.

- Inti hangat; Uap air yang naik ke atmosfir yang dingin akan mengembun dan melepaskan panas. Panas buangan tersebut didistribusikan secara vertikal pada bagian inti siklon tropis yang menyebabkannya terasa hangat.

- CDO (Central Dense Overcast); CDO merupakan daerah menyerupai pita melingkar di sekitar inti yang padat akan awan, hujan dan badai petir.

- Mata; Siklon tropis kuat seperti Hurricane memiliki mata yang berbentuk lubang melingkar di pusat sirkulasinya. Cuaca pada mata umumnya tenang dan tidak berawan. Pada siklon tropis lemah, CDO menutupi pusat sirkulasi sehingga mata tidak terlihat.

- Dinding mata; menyerupai pita melingkar di sekitar mata yang memiliki intensitas angin dan konveksi panas paling tinggi. Pada siklon tropis, kondisi pada dinding matalah yang paling berbahaya.

- Aliran keluar (outflow); Pada bagian atas siklon tropis, angin bergerak keluar dari pusat badai tropis dengan arah putaran berlawanan dengan siklon, sedangkan pada bagian bawah angin berputar kuat, melemah seiring dengan pergerakan naik dan akhirnya berbalik arah.

\subsection{Skala Kekuatan}

Untuk memberi gambaran kekuatan dan dampak yang bisa dihasilkan oleh Siklon Tropis / Hurricane maka dibuat pedoman skala kekuatan Hurricane. Skala yang umum digunakan adalah Skala Saffir-Simpson, yang dibagi atas lima kelas kategori (Debi I, 2001), seperti dijelaskan pada Tabel 1. sebagai berikut : 
Tabel 1. Skala Saffir-Simpson untuk Siklon Tropis : (Sumber : Wikipedia.org)

\begin{tabular}{|c|c|c|c|c|}
\hline $\begin{array}{c}\text { Kategori Saffir- } \\
\text { Simpson }\end{array}$ & $\begin{array}{c}\text { Kecepatan } \\
\text { angin maks. } \\
\left(\mathbf{m s}^{-1}, \mathbf{k t}\right)\end{array}$ & $\begin{array}{c}\text { Tek. udara } \\
\text { Minimum }(\mathbf{m b})\end{array}$ & $\begin{array}{c}\text { Storm surge } \\
(\mathbf{m}, \mathbf{f t})\end{array}$ & Contoh (tahun) \\
\hline 1 (Minimal) & $\begin{array}{c}33-42 \mathrm{~m} / \mathrm{s} \\
{[64-83 \mathrm{kt}]}\end{array}$ & $>=980 \mathrm{mb}$ & $\begin{array}{c}1.0-1.7 \mathrm{~m}[3- \\
5 \mathrm{ft}]\end{array}$ & $\begin{array}{c}\text { Danny (1985), Jerry (1989), Hernan (1996), } \\
\text { Claudette (2003), Gaston (2004), Humberto } \\
\text { (2007), Shary (2010), Barbara (2013). }\end{array}$ \\
\hline 2 (Moderat) & $43-49[84-96]$ & $979-965$ & $1.8-2.6[6-8]$ & $\begin{array}{c}\text { Diana (1990), Erin (1995), Alma (1996), Ernesto } \\
\text { (2012), Arthur (2014). }\end{array}$ \\
\hline 3 (Ekstentif) & $50-58[97-$ \\
$113]$ & $964-945$ & $\begin{array}{c}2.7-3.8[9- \\
12]\end{array}$ & $\begin{array}{c}\text { Carol (1954), Celia (1970), Alicia (1983), Roxanne } \\
\text { (1995), Fran (1996), Isidore (2002), Lane (2006), } \\
\text { Karl (2010), Sandy (2012) }\end{array}$ \\
\hline 4 (Ekstrim) & $\begin{array}{c}59-69[114- \\
135]\end{array}$ & $944-920$ & $\begin{array}{c}3.9-5.6[13- \\
18]\end{array}$ & $\begin{array}{c}\text { Hazel (1954), Audrey (1957), Flora (1963), Cleo } \\
\text { (1964), Frederic (1979), Joan (1988), Hugo } \\
\text { (1989), Iniki (1992), Luis (1995), Charley (2004), } \\
\text { Dennis (2005). }\end{array}$ \\
\hline 5 (Katastropik) & $>69[>135]$ & $<920 \mathrm{mb}$ & $>5.6[>18]$ & $\begin{array}{c}\text { Camille (1969), Anita (1977), David (1979), } \\
\text { Gilbert (1988), Andrew (1992), Dean (2007), Felix } \\
\text { (2007) }\end{array}$ \\
\hline
\end{tabular}

\subsection{Dampak Siklon Tropis}

Karena ukurannya yang sangat besar serta angin kencang dan gumpalan awan yang dimilikinya, siklon tropis menimbulkan dampak yang sangat besar pada tempat-tempat yang dilaluinya. Dampak ini bisa berupa angin kencang, hujan deras berjam-jam, bahkan berhari-hari yang dapat mengakibatkan terjadinya banjir, gelombang tinggi, dan gelombang badai (storm surge). Siklon tropis di laut dapat menyebabkan gelombang tinggi, hujan deras dan angin kencang yang mengganggu pelayaran internasional dan berpotensi untuk menenggalamkan kapal. Siklon tropis dapat memutar air dan menimbulkan gelombang laut yang tinggi. Di daratan, angin kencang dapat merusak atau menghancurkan kendaraan, bangunan, jembatan dan benda-benda lain, mengubahnya menjadi puing-puing beterbangan yang mematikan. Gelombang badai (storm surge) atau peningkatan tinggi permukaan laut akibat siklon tropis merupakan dampak yang paling buruk yang mencapai daratan.

Menurut sejarah, $90 \%$ siklon tropis mematikan. Perputaran siklon tropis yang mencapai daratan dan vertical wind shear di sekelilingnya akan menghasilkan tornado. Tornado dapat juga dihasilkan sebagai akibat dari vortisitas di dinding mata siklon yang tetap bertahan hingga mencapai daratan.

Dampak Langsung : Yang dimaksud sebagai dampak langsung siklon tropis adalah dampak yang ditimbulkan oleh siklon tropis terdapat daerah-daerah yang dilaluinya. Ini dapat berupa gelombang tinggi, gelombang badai atau storm surge yang berupa naiknya tinggi muka laut seperti air pasang tinggi yang datang tiba-tiba, hujan deras serta angin kencang. Contoh ketika suatu wilayah di Indonesia mengalami dampak langsung keberadaan siklon tropis adalah ketika terjadi peristiwa langka yaitu tumbuh siklon tropis Kirrily di atas Kepulauan Kai, Laut Banda, pada 27 April 2009. Kirrily menyebabkan hujan lebat dan storm surge di wilayah ini. Tercatat puluhan rumah rusak dan puluhan lainnya terendam, jalan raya rusak, dan gelombang tinggi terjadi dari 26 hingga 29 April. Curah hujan tercatat per 24 jam yang tercatat adalah di Tual adalah sebanyak $20 \mathrm{~mm}, 92 \mathrm{~mm}$ dan $193 \mathrm{~mm}$, masingmasing untuk tanggal 27, 28 dan 29 April 2009.

Dampak Tidak Langsung : Indonesia bukan merupakan daerah lintasan siklon tropis, namun demikia keberadaan siklon tropis di sekitar Indonesia, terutama yang terbentuk di sekitar Pasifik Barat Laut, Samudra Hindia Tenggara dan sekitar Australia akan mempengaruhi pembentukan pola cuaca di Indonesia. Perubahan pola cuaca oleh adanya siklon tropis inilah yang kemudian menjadikan siklon tropis memberikan dampak tidak langsung terhadap kondisi cuaca di wilayah Indonesia. Dampak tidak langsung atas adanya siklon tropis dapat berupa berbagai hal, diantaranya yaitu:

- Daerah pumpunan angin. Siklon tropis yang terbentuk di sekitar perairan sebelah utara maupun sebelah barat Australia seringkali mengakibatkan terbentuknya daerah pumpunan angin di sekitar Jawa atau Laut Jawa, NTB, NTT, Laut Banda, Laut Timor, hingga Laut Arafuru. Pumpunan angin inilah yang mengakibatkan terbentuknya lebih banyak awan-awan konvektif penyeab hujan lebat di daerah tersebut. Dilihat dari citra satelit, daerah pumpunan angin terlihat sebagai daerah memanjang yang penuh dengan awan tebal yang terhubung dengan perawanan siklon tropis, sehingga terlihat 
seolah-olah siklon tropis tersebut mempunyai ekor. Itulah sebabnya daerah pumpunan angin ini seringkali disebut sebagai ekor siklon tropis. Contoh kasus ketika Indonesia terkena ekor siklon tropis adalah pada saat terjadi siklon tropis George (2 Maret 2007) yang mengakibatkan adanya daerah pumpunan angin yang memanjang dari Jawa TImur hingga ke Nusa Tenggara Timur. Curah hujan yang tercatat pada saat itu di Ruteng, Waingapu, Rote, Kupang berturut-turut adalah sebanyak $172 \mathrm{~mm}, 52 \mathrm{~mm}, 78 \mathrm{~mm}, 73 \mathrm{~mm}$. Daerah pumpunan angin yang terbentuk oleh Siklon George (2007), membentuk ekor siklon yang menambah intensitas hujan di Jawa Timur hingga NTT.

- Daerah belokan angin. Adanya siklon tropis di perairan Samudra Hindia Tenggara menyebabkan terbentuknya daerah belokan angin di sekitar Sumatera bagian Selatan atau Jawa bagian Barat. Daerah belokan angin ini juga dapat mengakibatkan terbentuknya lebih banyak awan-awan konvektif penyebab hujan lebat di daerah tersebut.

- Daerah defisit kelembaban : Bersamaan dengan adanya siklon tropis di perairan sebelah utara Sulawesi atau di Laut Cina Selatan seringkali teramati bersamaan dengan berkurangnya curah hujan di wilayah Sulawesi bagian utara atau Kalimantan. Meskipun belum ada penelitian lebih lanjut, namun ditengarai bahwa fenomena ini disebabkan karena siklon tropis tersebut menyerap persediaan udara lembab yang terdapat dalam radius tertentu di sekitarnya, termasuk yang terkandung di atmosfer di atas Kalimantan dan Sulawesi bagian utara sehingga di wilayah ini justru udaranya kering dan kondisi cuacanya cenderung cerah tak berawan.

\subsection{Musim Siklon di Sekitar Indonesia}

Apakah Indonesia Dilalui oleh Siklon

Tropis? Menurut klimatologinya, wilayah Indonesia yang terletak di sekitar garis katulistiwa termasuk wilayah yang tidak dilalui oleh lintasan siklon tropis. Namun demikian banyak juga siklon tropis yang terjadi di sekitar wilayah Indonesia, dan memberikan dampak tidak langsung pada kondisi cuaca di Indonesia. Contohnya saja, siklon tropis Rosie (2008) yang terbentuk di sebelah barat Banten, siklon tropis Kirrily yang terbentuk di sekitar Kepulauan Aru, siklon tropis Inigo, yang pada saat masih berupa bibit siklon sempat melintasi Nusa Tenggara dan badai tropis Vamei (2001), yang diklaim sebagai badai tropis yang terbentuk paling dekat dengan katulistiwa yaitu di sekitar semenanjung Malaka, tepatnya pada koordinat $1.5^{\circ} \mathrm{LU}$. Dengan menggunakan data tahun 1964 hingga 2005 untuk kejadian siklon tropis di wilayah Samudra Hindia Tenggara dan tahun 1951 hingga 2006 untuk kejadian siklon tropis di wilayah Pasifik Barat Laut, telah dilakukan perhitungan untuk mendapatkan gambaran kejadian siklon tropis di wilayah dekat Indonesia terutama di wilayah antara $90^{\circ}$ hingga $150^{\circ} \mathrm{BT}$ dan $30^{\circ} \mathrm{LS}$ hingga $30^{\circ} \mathrm{LU}$.

Siklon Tropis di Sebelah Selatan Indonesia. Untuk siklon-siklon tropis di wilayah dekat Indonesia dengan histori data selama 42 tahun diketahui bahwa di sebelah Selatan siklon tropis terbanyak terjadi pada bulan Februari yaitu $23 \%$ kejadian dalam sebulan. Disusul kemudian dengan bulan Maret (22\%), Januari (21\%), Desember (14\%) dan April (11\%). Namun demikian pada bulan Juni, Juli, Agustus dan September diketahui merupakan bulan-bulan yang selama 42 tahun hampir tidak terdapat kejadian siklon tropis sama sekali.

Siklon tropis di wilayah ini paling sering terjadi pada bulan Februari yaitu 122 kejadian selama 42 tahun, dengan rata-rata kejadian mencapai 2,9 kejadian per tahun. Pada bulan ini kejadian siklon tropis terbanyak dialami pada tahun 1968 dimana pada saat itu terjadi 7 (tujuh) kali kejadian siklon tropis. Namun demikian ada saatnya pula di bulan Februari tidak terdapat satupun kejadian siklon tropis seperti pada tahun 1967, 1990 dan 2002. Bulan Desember yang merupakan bulan teraktif kedua, selama 42 tahun terdapat 76 kejadian siklon tropis dengan nilai rata-rata sebesar 1,8 kejadian per tahun. Kondisi ekstrim pernah dialami pada tahun 1973 dimana terdapat 6 kali kejadian siklon tropis dalam satu bulan. Pada bulan Juni dan Agustus terjadi frekuensi terkecil dimana selama 42 tahun tidak pernah sekalipun terdapat adanya kejadian siklon tropis.

Siklon tropis di sebelah utara Indonesia. Dengan data histori yang lebih panjang (56 tahun), diketahui bahwa wilayah dekat Indonesia sebelah Utara siklon tropis terbanyak terjadi pada bulan Agustus dimana 20\% siklon tropis terjadi pada bulan ini. Disusul kemudian dengan bulan September (18\%), Juli dan Oktober (15\%). $\mathrm{Di}$ bulan Agustus, dengan rata-rata kejadian sebanyak 5,2 kali siklon tropis per tahun, kondisi ekstrim maksimum pernah terjadi pada tahun 1960 (13 kali kejadian siklon tropis dalam sebulan) dan kondisi ekstrim minimum terjadi di tahun 1980 (hanya terjadi 2 kali kejadian siklon tropis dalam sebulan). Dan sebaliknya dengan jumlah kejadian terkecil 13 kali dalam 56 tahun, bulan Februari mengalami kejadian ekstrim maksimum pada tahun 1967 dan 1976 dengan 2 kali kejadian siklon tropis dan pada 45 tahun lainnya tidak mengalami siklon tropis sama sekali. 
Pada bulan Agustus yang merupakan bulan paling sibuk bagi pertumbuhan siklon tropis di wilayah ini, dari 323 kejadian terdapat 107 kejadian yang berkembang menjadi badai tropis dan 81 diantaranya berkembang lebih jauh menjadi hurricane. Di bulan Februari yang merupakan bulan dengan jumlah kejadian siklon tropis paling sedikit (13 kejadian), hanya terdapat satu siklon tropis yang berkembang menjadi hurricane.

\section{DATA DAN METODE}

Untuk melihat pengaruh kejadian siklon tropis terhadap kebakaran hutan digunakan data titik panas (hot spot) yang mengindikasikan adanya potensi / kejadian kebakaran hutan, meskipun keberadaan titik panas tidak selalu mencerminkan kejadian kebakaran hutan. Data yang dipakai adalah data hotspot yang diambil dari sipongi. Titik Panas atau yang lebih dikenal dengan hotspot adalah indikator kebakaran hutan yang mendeteksi suatu lokasi yang memiliki suhu relatif lebih tinggi dibandingkan dengan suhu disekitarnya (Kemenhut, 2009). Suhu kobaran api pada kebakaran liar biasanya sekitar $727^{\circ} \mathrm{C}$ namun karena satelit hanya mengukur area dengan luasan $1 \mathrm{~km}^{2}$ dan ada pula penyerapan atmosfer maka rata-rata suhu sekitar $27^{\circ} \mathrm{C}$ sampai $227^{\circ} \mathrm{C}$. Sedangkan treshold (nilai ambang) adalah nilai suhu kecerahan data satelit NOAA atau MODIS yang digunakan sebagai ambang batas dalam mengklasifikasikan hotspot. Sebagai contoh treshold SIPONGI DEPHUT untuk NOAA adalah $45^{\circ} \mathrm{C}$. Contoh yang lain treshold LAPAN NOAA adalah $47^{\circ} \mathrm{C}$ dan treshold ASMC NOAA $47^{\circ} \mathrm{C}$.

Satelit yang dapat dimanfaatkan untuk memantau hotspot adalah satelit NOAA dan Modis. Satelit NOAA (National Oceanic and Atmospheric Administration) dengan sensor AVHRR (Advanced Very High Resolution Radiometer) mampu untuk mendeteksi kebakaran hutan, analisa vegetasi, analisa ramalan cuaca, penelitian dan ramalan iklim, pengukuran suhu permukaan laut global, penelitian pencarian dan penyelamatan laut. Satelit NOAA pertama kali (NOAA 6) diluncurkan pada tahun 1979. Diikuti dengan serangkain satelit NOAA tambahan dan 2 (dua) satelit NOAA yang terakhir diluncurkan adalah NOAA18 pada 20 Mei 2005 dan NOAA19 pada 6 Pebruari 2009. Satelit MODIS (Moderate Resolution Imaging Spectroradiometer) terdiri dari 2 (dua) satelit yaitu TERRA MODIS dan AQUA MODIS. Dengan data MODIS akan meningkatkan pemahaman tentang perubahan global dan proses yang terjadi di darat, laut dan di lapisan atmosfer rendah. Untuk melihat pengaruh kejadian siklon di suatu wilayah diperlukan analisis hujan wilayah dalam rentang waktu tahun 2012. Untuk itu diperlukan data curah hujan yang mempunyai kecakupan keruangan dan waktu yang memadai.
Data curah hujan yang dipakai dalam penelitian ini adalah data curah hujan wilayah yang diambil dari satelit Tropical Rainfall Measuring Mission (TRMM).

Data TRMM adalah data precipitasi (curah hujan) yang didapat dari satelit meteorologi TRMM dengan sensornya PR (Precipitation Radar), TMI (TRMM Microwave Imager), dan VIRS (Visible and Infrared Scanner), CERES (Clouds and the Earth's Radiant Energy System), dan LIS (Lightning Imaging Sensor). Satelit TRMM tersebut merupakan hasil kerjasama dua badan antariksa nasional, yaitu Amerika Serikat NASA (National Aeronautics and Space Administration) dan Jepang NASDA (National Space Development of Japan), sekarang berubah menjadi JAXA : (Japan Aerospace Exploration Agency).

Produk terakhir dari JAXA berupa Global Rainfall Map in Near-Real-Time (GSMaP_NRT) yang tersedia empat jam setelah pengamatan dengan resolusi temporal setiap jam dan resolusi spasial $0.1^{\circ}$ geografis sehingga analisis menggunakan data tersebut cukup memadai (JAXA, 2013). Sistem ini didasarkan pada kombinasi algoritma MW-IR yang memakai TRMM TMI, Aqua AMSR-E, DMSP SSM/I dan SSMIS, NOAA-19 AMSU dan MetOp-A AMSU, dan GEO IR yang dikembangkan oleh proyek GSMaP (Global Satellite Mapping of Precipitation). Data format binary telah tersedia secara archieve dan bias diunduh dengan fasilitas file transfer protocol (ftp) di : ftp://hokusai.eorc.jaxa.jp/realtime/archive/.

Metode yang dilakukan adalah analisis kejadian siklon selama tahun 2012 di wilayah Pasifik Barat dan Laut China Selatan.

\section{DISKUSI}

Diskusi ini dikhususkan untuk melakukan analisis siklon tropis di wilayah Pasifik Barat dan Laut China Selatan dan tidak dilakukan untuk wilayah lainnya. Di wilayah Pasifik Barat dan Laut China Selatan telah terjadi beberapa Siklon tropis dalam beberapa skala kekuatan (kategori) seperti terlihat pada Tabel 2.

Dari Tabel 2. terlihat bahwa selama tahun 2012 setidaknya ada kejadian 13 (tiga belas) kejadian siklon tropis. Super typhoon "Jelawat" merupakan siklon tropis terkuat dengan kategori 5 (Katastropik) dengan kecepatan angin maksimum mencapai 260 knot dan tekanan udara minimum mencapai 918 mbar. Super typhoon "Guchol" merupakan siklon tropis terkuat kedua terkuat dengan kategori 4 (ekstrim) dengan kecepatan angin maksimum mencapai 240 knot dan tekanan udara minimum mencapai 926 mbar. 
Tabel 2. Kejadian siklon tropis tahun 2012 di wilayah Pasifik Barat dan Laut China Selatan :

\begin{tabular}{|c|c|c|c|c|c|}
\hline No & Nama & Kategori & Periode aktif & $\begin{array}{c}\text { Kecepatan angin } \\
\text { maksimum (kt) }\end{array}$ & $\begin{array}{c}\text { Tekanan udara } \\
\text { minimum (mb) }\end{array}$ \\
\hline 1 & Mawar (Ambo) & Typhoon (3) & 31 May-05Juni 2012 & $185 \mathrm{kph}(100 \mathrm{kt})$ & 948 \\
\hline 2 & Guchol (Butchoy) & Super Typhoon (4) & $11-18$ Juni 2012 & $240 \mathrm{kph}(130 \mathrm{kt})$ & 926 \\
\hline 3 & Talim (06W) & Tcopical Storm & 18-21 Juni 2012 & $85 \mathrm{kph}(45 \mathrm{kt})$ & 989 \\
\hline 4 & Doksuri (Dindo) & Tcopical Storm & 27-29 Juni 2012 & $65 \mathrm{kph}(35 \mathrm{kt})$ & 996 \\
\hline 5 & Saola (Gener) & Typhoon (3) & 27 Juli - 03 Ags 2012 & $165 \mathrm{kph}(90 \mathrm{kt})$ & 956 \\
\hline 6 & Kai-Tak (Helen) & Tcopical Storm & 13-16 Agustus 2012 & $100 \mathrm{kph}(55 \mathrm{kt})$ & 982 \\
\hline 7 & Tembin (Igme) & Typhoon (3) & 19-28 Agustus 2012 & $185 \mathrm{kph}(100 \mathrm{kt})$ & 948 \\
\hline 8 & Jelawat (Lawin) & Super Typhoon (5) & 21-29 September & 260kph(140kt) & 918 \\
\hline 9 & Gaemi (Marce) & Tcopical Cyclone & 02-05 Oktober 2012 & $75 \mathrm{kph}(40 \mathrm{kt})$ & 993 \\
\hline 10 & Prapiron (Nina) & Typhoon (3) & 08-18 Oktober 2012 & $185 \mathrm{kph}(100 \mathrm{kt})$ & 948 \\
\hline 11 & Son-Tinh (Ofel) & Tcopical Cyclone & 24-26 Oktober 2012 & $100 \mathrm{kph}(55 \mathrm{kt})$ & 982 \\
\hline 12 & Bopha (Pablo) & Tcopical Cyclone & 26 Nov-9 Des 2012 & $100 \mathrm{kph}(55 \mathrm{kt})$ & 982 \\
\hline 13 & Wukong(Quinta) & Tcopical Cyclone & 25-27 Desember 2012 & $65 \mathrm{kph}(35 \mathrm{kt})$ & 996 \\
\hline
\end{tabular}

Dari Tabel 2 dapat juga diperlihatkan bahwa kejadian siklon tropis mulai ada pada bulan Mei sampai bulan Desember, sedangkan pada bulan Januari sampai April untuk wilayah Pasifik Barat dan Laut China Selatan tidak ada kejadian siklon tropis. Pada Bulan May 2012 terdapat 1 (satu) kejadian siklon tropis, pada bulan Juni 2012 terdapat 4 (empat) kejadian, bulan Juli 20121 (satu) kejadian, bulan Agustus 20123 (tiga) kejadian, September 20121 (satu) kejadian, Oktober 20123 (tiga) kejadian, November 1 (satu) kejadian dan Desember 2012 terdapat 2 (dua) kejadian siklon tropis.

\section{a. Lintasan Siklon tropis}

Lintasan siklon tropis umumnya bergerak dari Timur ke Barat. Karena pengaruh efek Coriolis maka lintasan siklon tropis selalu menjauhi garis khatulistiwa. Menurut klimatologinya, wilayah Indonesia yang terletak di sekitar garis katulistiwa termasuk wilayah yang tidak dilalui oleh lintasan siklon tropis. Untuk wilayah Samudera Pasifik bagian barat dan Laut Cina Selatan, Filipina dan Taiwan merupakan Negara yang paling serius mendapatkan dampak langsung Siklon tropis karena berada di daerah lintasan siklon tropis. Berikut adalah contoh lintasan siklon tropis Jelawat yang sudah kategori super typhoon.

Terkadang kemunculan siklon tropis dibarengi dengan kemunculan siklon tropis lainnya. Seperti terlihat pada Gambar 2. di bawah ini yang menunjukkan adanya siklon tropis Prapiroon (Nina) di saat yang sama terdapat juga kejadian siklon tropis Maria yang terjadi pada bulan Oktober 2012. Kejadian ini biasanya akan menambah lama umur salah satu siklon tropis tersebut, dikarenakan siklon tropis yang satunya saling berpengaruh terhadap siklon tropis yang lainnya yang dikenal dengan Fujiwhara effect.

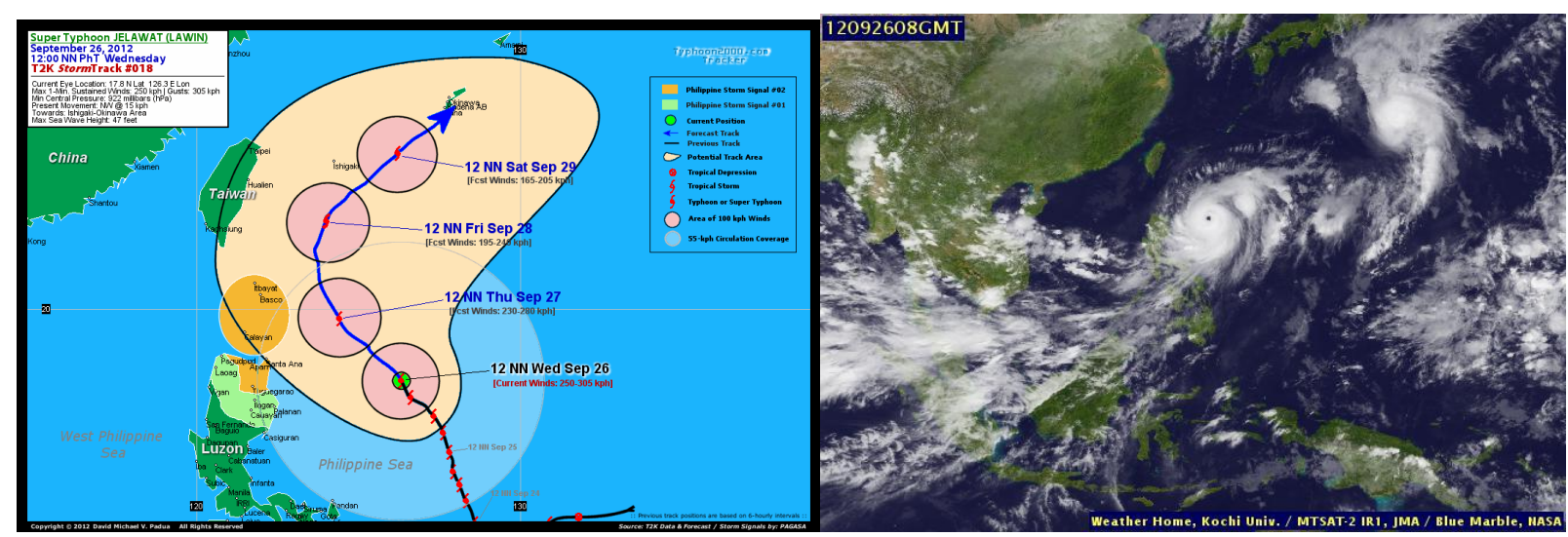

Gambar 2. Lintasan Super Typhoon Jelawat dan citra satelit yang terjadi 


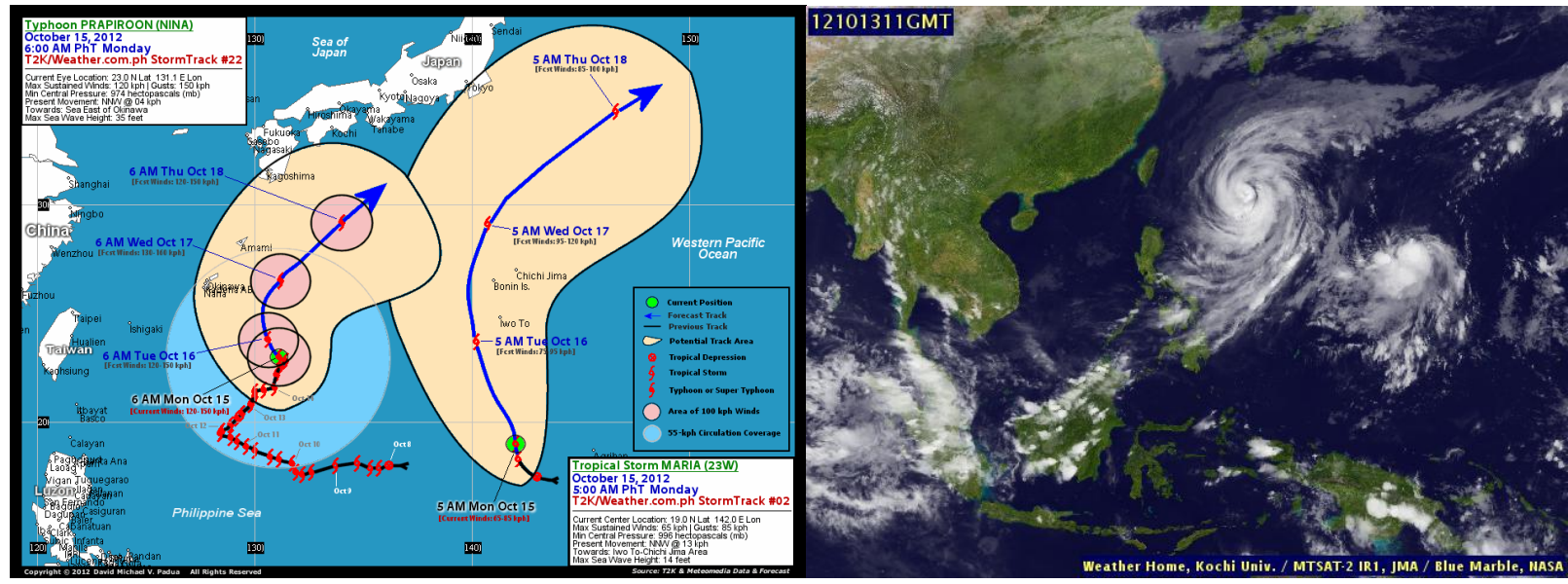

Gambar 3. Lintasan Super Typhoon Prapiporn (Nina) dan citra satelit yang terjadi

\section{b. Pengaruh Siklon tropis terhadap Kejadian Titik Panas (Hotspot)}

Seperti telah dijelaskan di atas bahwa wilayah Indonesia mendapatkan pengaruh secara tidak langsung dari keberadaan siklon tropis, salah satunya adalah bencana kekeringan di sebagian wilayah di Indonesia. Hal ini terjadi karena keberadaan siklon tropis yang dekat dengan perairan wilayah Indonesia akan menarik massa uap air dari perairan wilayah Indonesia menuju ke titik pusat tekanan rendah system siklon tropis tersebut sehingga udara di wilayah tersebut menjadi cukup kering dan sulit terbentuknya awan.

Wilayah yang mendapat pengaruh tersebut adalah sebagian wilayah Kalimantan dan sebagian wilayah Sumatera. Akibat dari tingkat kekeringan yang cukup tinggi ditambah perilaku masyarakat di wilayah hutan dan lahan yang kurang bertanggung jawab dalam melakukan pembukaan lahan (land clearing) maka terjadi peningkatan jumlah titik panas (hotspot) yang berakibat semakin paraknya tingkat kekeringan. Kondisi tersebut akan lebih parah jika keberadaan siklon tropis terjadi pada bulan bulan kering yang umumnya bersesuaian dengan perilaku masyarakat dalam melakukan pembukaan lahan.

Gambar 4. adalah distribusi hotspot untuk Sumatera dan Kalimantan sepanjang tahun 2012, sedangkan Gambar 5. adalah jumlah hotspot bulanan untuk Pulau Sumatera dan Pulau Kalimantan selama tahun 2012.

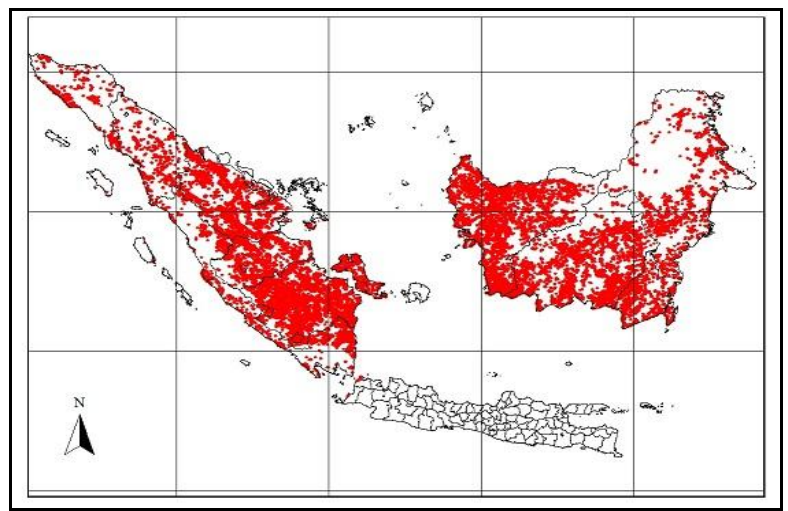

Gambar 4 Distribusi hotspot untuk Sumatera dan Kalimantan sepanjang tahun 2012

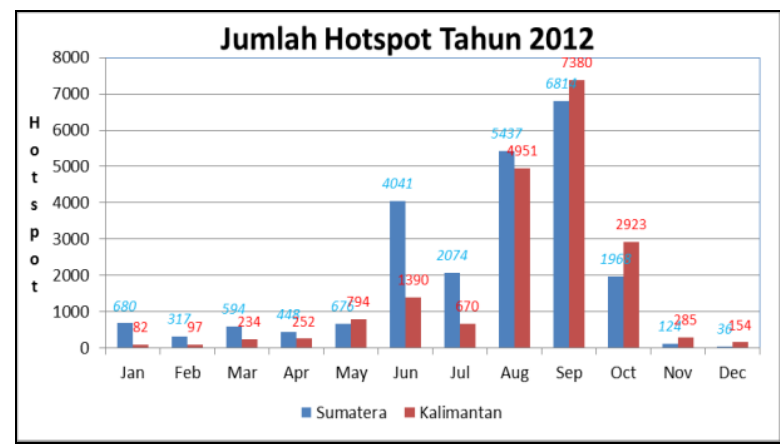

Gambar 5. Jumlah Hotspot tahun 2012 untuk Sumatera dan Kalimantan. (sumber : NASA)

Dari Gambar 4. terlihat bahwa konsentrasi hotspot terjadi di propinsi-propinsi Kalimantan Barat, Kalimantan Tengah, Kalimantan Selatan, Riau, Jambi dan Sumatera Selatan yang berdekatan dengan perairan laut China Selatan sebagai daerah lintasan siklon tropis. Sedangkan dari Gambar 5. menjelaskan bahwa puncak jumlah hotspot untuk kedua wilayah Kalimantan dan Sumatera terjadi pada bulan September 2012 dimana intensitas siklon tropis terjadi pada bulan Agustus sampai Oktober seperti pada Tabel 2. Hal ini menunjukkan bahwa pengaruh keberadaan siklon tropis berkaitan erat dengan jumlah hotspot di kedua wilayah tersebut. Sepanjang tahun 2012 sekitar 19200 buah hotspot terdeteksi di wilayah Kalimantan sementara untuk wilayah Sumatera terdeteksi sekitar 23.200 buah (sumber : NASA 2012). Untuk wilayah Sumatera pada tahun 2012 bulan dengan jumlah hotspot tertinggi terjadi pada bulan September dengan jumlah hotspot mencapai 6814 buah, sementara untuk wilayah Kalimantan pada tahun yang sama jumlah hotspot tertinggi juga terjadi pada bulan September dengan jumlah mencapai 7380. Secara time series terlihat seperti pada Gambar 5. 


\section{c. Pengaruh Siklon tropis terhadap Kejadian Hujan}

Analisis dilakukan terhadap curah hujan di wilayah : DAS Citarum Propinsi Jawa barat, DAS Kotopanjang Propinsi Riau, DAS Riamkanan Propinsi Kalimantan Selatan, Wilayah Pontianak Kalimantan Barat dan wilayah Palangkaraya Kalimantan Tengah.

Untuk mengatasi ketiadaan data penakar hujan, digunakan data dari satelit TRMM. Data TRMM dengan tipe GSMap_NRT dari Japan Aerospace Exploration Agency (JAXA). Resolusi horizontal GSMaP_NRT adalah $0,1^{\circ}$ lintang / bujur, sedangkan resolusi spasialnya adalah satu jam. Data gsmap_nrt dari Jaxa ini telah dilakukan validasi dan kalibrasi dengan data penakar maupun data radar di Jepang dengan hasil validasi yang cukup baik.

Gambar 6. dan Gambar 7. menunjukkan plot time series curah hujan harian wilayah DAS Citarum Jawa Barat dan DAS Kotopanjang Riau selama tahun 2012, Garis bar menunjukkan kejadian siklon tropis.
Gambar 8, Gambar 9 dan Gambar 10. menunjukkan plot time series curah hujan harian wilayah DAS Riamkanan Kalimantan Selatan,Wilayah Pontianak Kalimantan Barat dan Wilayah Palangkaraya Kalimantan Tengah selama tahun 2012, Garis bar menunjukkan kejadian siklon tropis.

Untuk wilayah DAS Citarum seperti terlihat pada Gambar 6, menunjukkan bahwa keberadaan siklon tropis yang mulai terjadi pada bulan Juni 2012 yang bersesuaian dengan masuknya musim panas semakin mengurangi jumlah curah hujan di wilayah tersebut. Kondisi ini berlanjut sampai bulan Oktober dimana seharusnya pada bulan tersebut sudah mulai masuk musim hujan. Keberadaan siklon tropis pada bulan Oktober 2012 menyebabkan curah hujan berkurang di wilayah tersebut, sementara keberadaan siklon tropis di bulan Desember tidak begitu mempengaruhi dalam pengurangan curah hujan di wilayah tersebut.

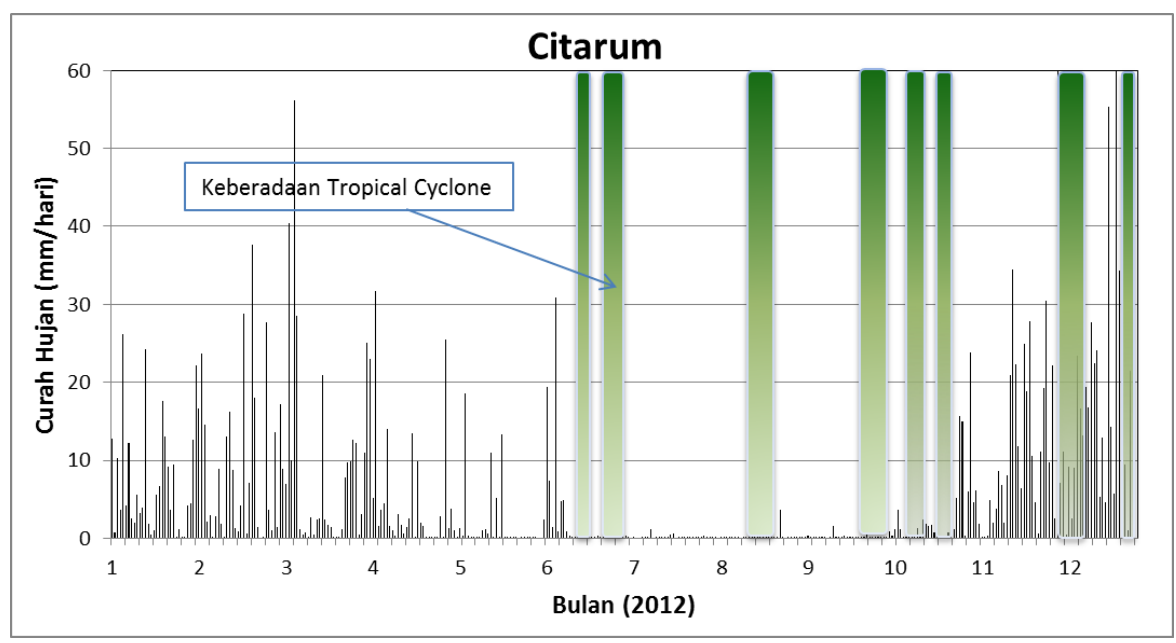

Gambar 6. Curah hujan harian wilayah DAS Citarum Jawa Barat tahun 2012, garis bar menunjukkan kejadian siklon tropis

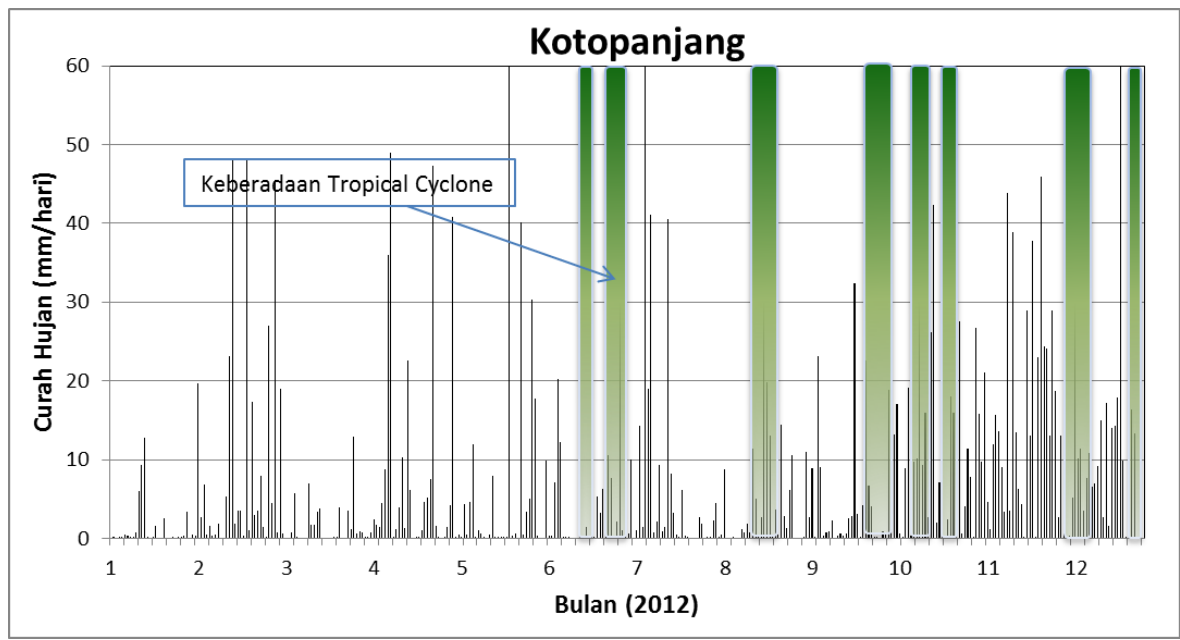

Gambar 7. Curah hujan harian wilayah DAS Kotopanjang Riau tahun 2012, garis bar menunjukkan kejadian siklon tropis 


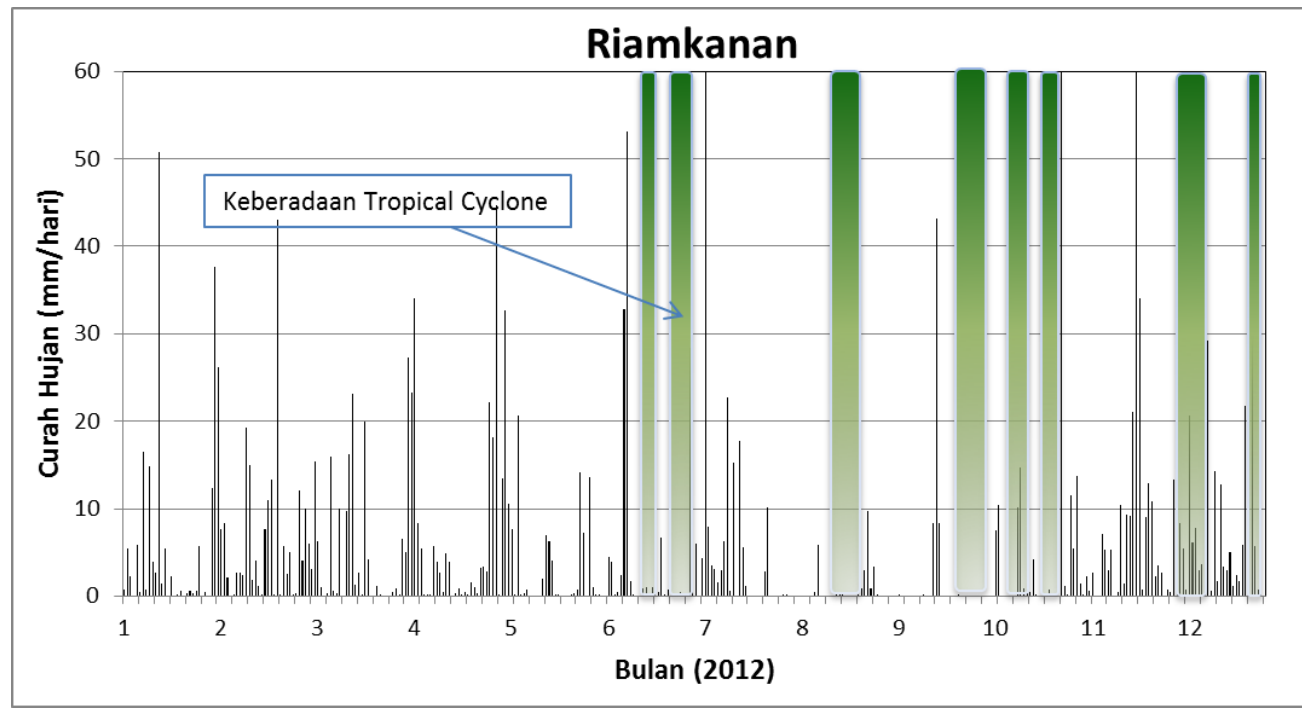

Gambar 8. Curah hujan harian wilayah DAS Riamkanan Kalimantan Selatan tahun 2012, garis bar menunjukkan kejadian siklon tropis

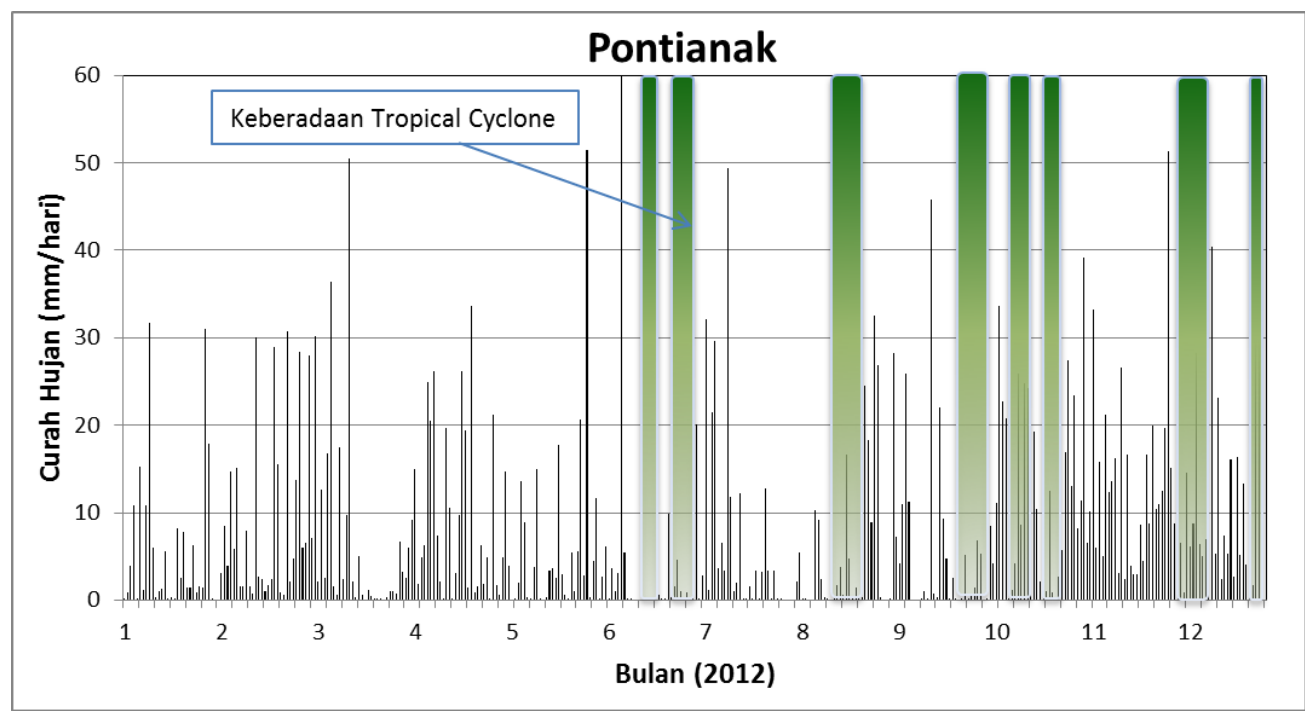

Gambar 9. Curah hujan harian wilayah Wilayah Pontianak Kalimantan Barat tahun 2012, garis bar menunjukkan kejadian siklon tropis

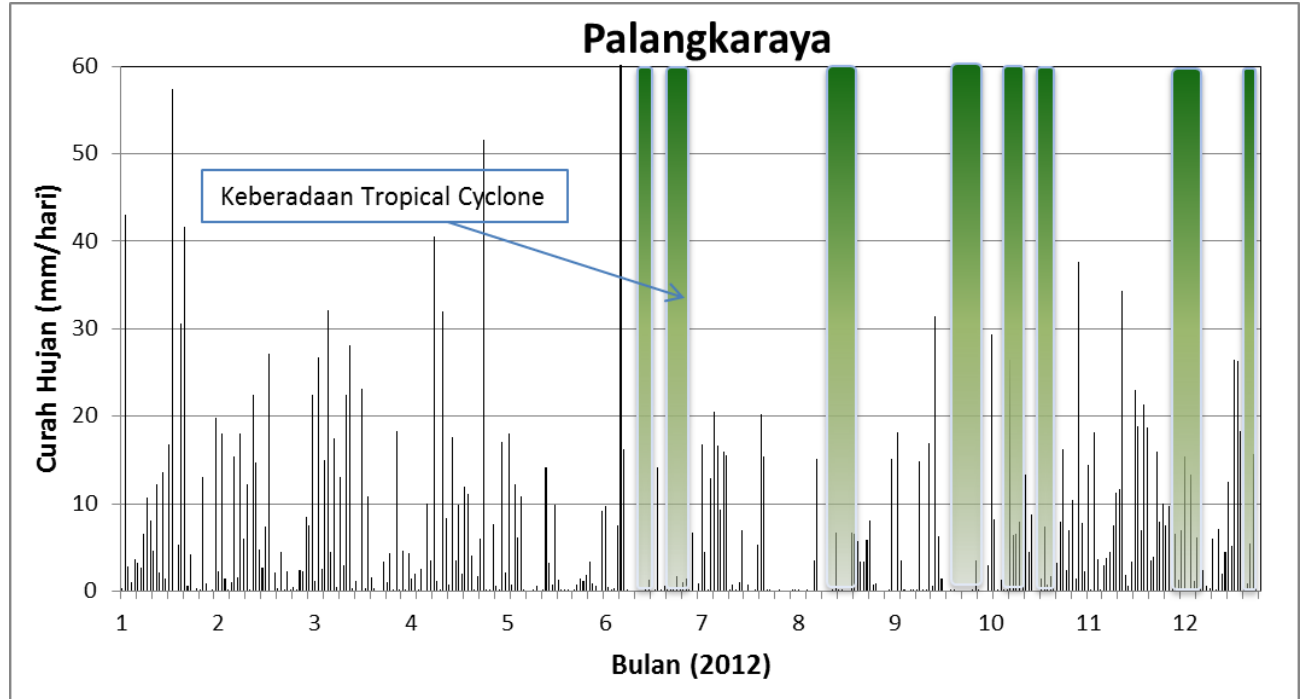

Gambar 10. Curah hujan harian wilayah Palangkaraya Kalimantan Tengah tahun 2012, garis bar menunjukkan kejadian siklon tropis. 
Untuk wilayah DAS Kotopanjang Riau, pengaruh siklon tidak tampak jelas dengan pengurangan curah hujan seperti terlihat dari Gambar 7, karena biasanya keberadaan siklon tropis menarik massa udara di samudera hindia ke arah pusat siklon (Laut Cina Selatan) dan sebagian masih berada di wilayah pesisir timur sumatera yang masih berpeluang untuk pertumbuhan awan di DAS tersebut.

Untuk wilayah DAS Riamkanan seperti terlihat pada Gabar 8, menunjukkan pengaruh keberadaan siklon tropis yang kurang begitu kuat ketika terjadi pada bulan basah, tetapi ketika terjadi pada bulan kering (Agustus) maka akan semakin memperkecil peluang kejadian hujan.

Untuk wilayah Kalimantan yaitu Pontianak dan Palangkaraya distribusi curah hujan selama satu tahun terlihat hamper merata dan tidak terpengaruh secara ekstrim terhadap keberadaan siklon tropis. Hal ini karena posisi wilayah tersebut yang relative lebih dekan dengan pusat siklon tropis (Laut Cina Selatan) dibandingkan dengan wilayah lain. Massa udara yang tertarik ke pusat siklon tropis sebagian masih berada di kedua wilayah tersebut sehingga masih ada massa udara basah untuk pertumbuhan awan. Secara umum pengaruh keberadaan siklon tropis tidak sama untuk masing-masing wilayah di Sumatera dan Kalimantan.

\section{KESIMPULAN}

Badai tropis merupakan fenomena meteorologis yang sangat potensial menimbulkan dampak kerusakan pada daerah yang dilaluinya. Kekuatan alam pada badai tropis begitu besar dan tak ada upaya manusia yang mampu mencegah atau menghilangkan badai tropis.

Indonesia umumnya menerima dampak tidak langsung pada perubahan kondisi cuaca. Pada musim kering kejadian tropical cuclone akan menambah parah tingkat kekeringan di wilayah Indonesia khususnya Sumatera dan Kalimantan dan berakibat munculnya jumlah titik api (hot spot) yang cukup banyak.

Pada musim basah kejadian siklon tropis dapat menyebabkan peningkatan curah hujan penyebab banjir terutama di wilayah yang dekat dengan lokasi siklon misalnya di wilayah Kalimantan dan Sulawesi bagian utara.

\section{DAFTAR PUSTAKA}

Badan Meteorologi Klimatologi dan Geofisika, 2011, Tropical Cyclone Warning Center, Jakarta

Pustekkom, 20015, Badai Tropis. Diakses di : http://idkf.bogor.net/yuesbi/e-DU.KU/ edukasi.net/Fenomena.Alam/Badai/all.htm \#skala

Williams, Jack (May 17, 2005). "Hurricane scale invented to communicate storm danger". USA Today. Retrieved February 25, 2007

Debi lacovelli (July 2001). "The Saffir/Simpson Hurricane Scale: An Interview with Dr. Robert Simpson". Sun-Sentinel. Fort Lauderdale, Fla. Retrieved September 10, 2006.

Xie, P., A. Yatagai, M. Chen, T. Hayasaka, Y. Fukushima, C. Liu, and S. Yang. 2007. A Gauge-Based Analysis of Daily Precipitation over East Asia. Journal of Hydrometeorology, 8. 607-626.

Japan Aerospace Exploration Agency Earth Observation Research Center, 2013, User's Guide for Global Rainfall Map in Near-Real-Tim e by JAXA Global Rainfall Watch (GSMaP_NRT), Version 2.4

Direktorat Pengendalian Kebakaran Hutan, Direktorat Jenderal PHKA Kementerian Kehutanan, 2012. Informasi Sebaran Hotspot, http://ditpkh-phka.dephut.go.id/

Matthew C. Wheeler and Harry H. Hendon, An All-Season Real-Time Multivariate MJO Index: Development of an Index for Monitoring and Prediction, American Meteorological Society, 2004

UPT Hujan Buatan, Laporan Hasil Kegiatan Pemanfaatan Teknologi Modifikasi Cuaca (TMC) Untuk Menanggulangi Bencana Asap Kebakaran Lahan dan Hutan di Propinsi Jambi Tahun 2012. Jakarta, 2012.

World Meteorological Organization, EINino / La Nina Updated, June 2012. 